\title{
ANALISA KEBUTUHAN AIR BERSIH DI KOTA MEDAN SUMATERA UTARA
}

\author{
Salomo Simanjuntak ${ }^{1}$, Eben Oktavianus Zai, ${ }^{2}$ \\ Michael Halomoan Tampubolon, ${ }^{3}$ \\ Fakultas Teknik Universitas HKBP Nommensen, Medan \\ Email: $\underline{\text { salomojuntak679@yahoo.co.id }}{ }^{1}, \underline{\text { eben.zai@uhn.ac.id }}^{2}$, \\ halomoanmichael@gmail.com ${ }^{3}$.
}

\begin{abstract}
Humans need or consume good quality water every day, which is called clean water with certain standards. Clean water is a type of water-based resource that is of good quality and is commonly used by humans for consumption or in carrying out their daily activities, including sanitation. According to doctors and health experts, the consumption of water needed by the body is as much as 2.5 liters or the equivalent of 8 glasses per day. The initial stage in this research is to first collect the required data from the Central Statistics Agency and the Medan City BAPPEDA with literature studies and ask questions directly to related parties about the data needed. Then the calculation of the projected population in the Medan City area is carried out using geometric and arithmetic methods. The next stage is to calculate the need for clean water in Medan City and calculate the maximum daily water needs and peak hours. From the results of the analysis starting in 2018 (beginning of planning) to 2025 (end of planning) the amount of clean water needs always increases every year along with the increase in population each year.
\end{abstract}

Key word: Clean water demand data, calculation of clean water needs, geometric \& arithmetic methods

\begin{abstract}
Abstrak
Manusia memerlukan atau mengkonsumsi air yang berkualitas baik setiap hari yaitu yang disebut dengan air bersih dengan standar tertentu. Air bersih adalah salah satu jenis sumber daya berbasis air yang bermutu baik dan biasa dimanfaatkan oleh manusia untuk dikonsumsi atau dalam melakukan aktivitas mereka sehari-hari termasuk diantaranya adalah sanitasi. Menurut dokter dan para ahli kesehatan, konsumsi air yang dibutuhkan oleh tubuh adalah sebanya 2,5 liter atau setara dengan 8 gelas setiap harinya. Tahapan awal yang dilakukan dalam penelitian ini ialah terlebih dahulu mengumpulkan data yang dibutuhkan dari Badan Pusat Statistik dan BAPPEDA Kota Medan dengan kajian-kajian pustaka dan mengajukan pertanyaan langsung ke pihak terkait tentang data yang dibutuhkan. Kemudian dilakukan perhitungan proyeksi jumlah penduduk yang ada di wilayah Kota Medan dengan menggunakan metode geometrik, aritmatika. Tahap berikutnya adalah menghitung kebutuhan air bersih di Kota Medan serta menghitung kebutuhan air harian maksimum dan jam puncak. Dari hasil analisis mulai tahun 2018 (awal perencanaan) sampai dengan tahun 2025 (akhir perencanaan) jumlah kebutuhan air bersih selalu mengalami kenaikan tiap tahun seiring dengan bertambahnya juga jumlah penduduk tiap tahun.
\end{abstract}

Kata Kunci: Data Kebutuhan air bersih, Perhitungan Kebutuhan Air Bersih, Metode Geometrik \& Aritmatik.

Received May 2 ${ }^{\text {rd }}$, 2021; Revised June 5 ${ }^{\text {th }}$ 2021; Accepted July, 2021 


\section{PENDAHULUAN}

Elemaen Air yang paling dibutuhkan untuk berlangsungnya kehidupan makhluk hidup di bumi. Air yang dibutuhkan manusia ialah air bersih, dimana menurut Peraturan Menteri Kesehatan R.I No. 416/MENKES/PER/IX/1990 Persyaratan Kualitas Air Bersih, air yang memenuhi syarat kesehatan ialah jernih, tidak berbau, tidak berasa, tidak berwarna, tidak mengandung kuman dan zat-zat berbahaya. Air bersih merupakan kebutuhan pokok manusia, dimana kebutuhannya dari hari kehari dirasakan semakin meningkat sejalan dengan pertumbuhan jumlah penduduk dan ketergantungan masyarakat dan juga pola hidup masyarakat terhadap air. Air bersih merupakan salah satu faktor penting bagi kesehatan manusia. Maka dari itu air bersih pun menjadi salah satu dari sekian banyak kebutuhan yang sangat diprioritaskan bagi seluruh makhluk hidup.

Bagi manusia, air bersih berperan penting dalam berbagai macam bentuk kegiatan sehari-hari. Dalam keperluan rumah tangga saja misalnya, air bersih banyak digunakan untuk keperluan mencuci, memasak makanan dan minuman serta keperluan-keperluan mandi cuci kakus dan lain sebagainya.

Berdasarkan berbagai kebutuhan itulah maka dilakukan usaha-usaha guna memenuhi kebutuhan air bersih yang dapat digunakan oleh masyarakat luas. Kota Medan merupakan kota metropolitan dan memiiki jumlah penduduk sebesar 2 juta jiwa, maka bisa di perkirakan kebutuhan air bersih Kota Medan yaitu 150/liter/hari/jiwa. Dalam Perpres Nomor 33 tahun 2011 tentang Kebijakan Nasional Pengelolaan Sumber Daya Air disebutkan bahwa dalam pemenuhan air tersebut manusia melakukan berbagai upaya untuk mendapatkannya dan dalam usaha pemenuhan kebutuhan air bersih untuk masyarakat ini tidak akan terlepas dari proses penyediaan/produksi air bersih. Karena pada prinsipnya, semakin betambah mausia, maka kebutuhan dalam segi pemenuhan air bersih juga akan semakin meningkat, sehingga sangatlah diperlukan analisis proyeksi kebutuhan air bersih di Kota Medan untuk beberpa tahun kedepan. Dalam hal ini dicanangkan kebutuhan air bersih di Kota Medan pada tahun 2025 kedepan.

\section{TINJAUAN PUSTAKA}

\section{Pengertian Air Bersih}


Jurnal Visi Eksakta (JVIEKS)

Vol.2, No.2, Juli 2021, pp.186-204

https://ejournal.uhn.ac.id/index.php/eksakta/

Air Bersih adalah salah satu jenis sumber daya berbasis air yang bermutu baik dan biasa dimanfaatkan oleh manusia untuk dikonsumsi atau dalam melakukan aktivitas mereka sehari-hari dan memenuhi persyaratan untuk pengairan sawah, untuk treatment air minum dan untuk treatment air sanitasi. Persyaratan ditinjau dari persyaratan kandungan kimia, fisik dan biologis. Menurut Permenkes No.492/2010 Air Minum adalah air yang melalui proses pengolahan atau tanpa proses pengolahan yang memenuhi syarat kesehatan yang dapat langsung diminum.

\section{Fungsi dan Peranan Air Bagi Kehidupan}

\section{Manfaat Air bagi Manusia}

Kegunaan air bagi tubuh manusia antara lain adalah untuk membantu proses pencernaan, mengatur metabolisme tubuh, mengangkut zat-zat makanan dalam tubuh, mengatur keseimbangan tubuh dan menjaga tubuh agar tidak kekeringan. Menurut dokter dan para ahli kesehatan, konsumsi air yang dibutuhkan oleh tubuh adalah sebanya 2,5 liter atau setara dengan 8 gelas setiap harinya.

\section{Manfaat Air bagi Hewan}

Tidak jauh berbeda dengan manusia, hewan juga membutuhkan air sebagai alat bantu untuk proses pencernaan dan juga mengatur suhu tubuh serta menjaga metabolisme tubuh hewan. Dan khusus bagi hewan air, air adalah sebagai sarana utama bagi tempat tinggal hewan tersebut. Tanpa adanya air, hewan-hewan yang memiliki habitat air tidak akan mampu bertahan hidup, seperti ikan, mamalia laut dan amfibi..

\section{Manfaat Air bagi Tumbuhan}

Kelangsungan hidup tumbuhan sangat bergantung pada jumlah air yang tersedia. Kegunaan air bagi tumbuhan antara lain untuk menjaga proses pertumbuhan serta menjaga agar tumbuhan tidak mengalami kekeringan. Dan apabila tumbuhan kekurangan suplai air, maka tumbuhan akan mengalami kekeringan yang mengakibatkan tumbuhan tersebut akan mati.

\section{Sumber Air Bersih}

Ada berbagai macam sumber air yang dapat dimanfaatkan sebagai sumber air bersih, yakni diantaranya ialah:

1. Air Atmosfir

Received May 2 $2^{\text {rd }}$ 2021; Revised June 5 ${ }^{\text {th }}$ 2021; Accepted July, 2021 
Air atmosfir adalah air yang asalnya dari udara atau atmosfir yang jatuh ke permukaan bumi. Karena dengan adanya pengotoran udara yang disebabkan oleh kotoran-kotoran industri/debu dan lain sebagainya, maka untuk menjadikan hujan sebagai sumber air minum hendaknya pada waktu menampung air hujan jangan dimulai pada saat hujan mulai turun karena masih mengandung banyak kotoran.

2. Air Permukaan

Air permukaan adalah air hujan yang mengalir di permukaan bumi. Air permukaan terbagi kedalam dua macam, yaitu: Air sungai dan air rawa/danau. Air sungai yang digunakan sebagai air bersih dan air minum harus melewati proses pengolahan terlebih dahulu dengan sempurna. Sementara itu Air rawa/Danau juga harus melewati pengolahan yang sama karena biasanya dalam air rawa/danau banyak terkandung zat-zat organik yang telah membusuk yang menyebabkan warna air rawa/danau menjadi kuning kecokelatan.

\section{Air Tanah}

Air tanah adalah air yang berada di bawah permukaan tanah di dalam zona jenuh dimana tekanan hidrostatiknya sama atau lebih besar dari tekanan atmosfer. Air tanah terbagi ke dalam air tanah dangkal dan air tanah dalam. Air tanah dangkal adalah air tanah yang terjadi karena adanya proses peresapan air ke dalam tanah. Sementara air tanah dalam adalah air tanah yang terdapat setelah lapis rapat air tanah yang pertama.

\section{Mata Air}

Mata air adalah air tanah yang keluar dengan sendirinya dari permukaan tanah dengan hampir tidak dipengaruhi oleh perubahan musim yang kualitasnya tidak jauh berbeda dengan air dalam. Mata air terbagi ke dalam dua jenis, yaitu rembesan yang merupakan mata air yang keluar dari lereng-lereng perbukitan atau pegunungan dan umbul yang merupakan mata air yang keluar ke permukaan pada suatu dataran.

\section{Persyaratan dalam Penyediaan Air Bersih}

Menurut Sutrisno, T, dkk (2010: 21) ada beberapa persyaratan dalam penyediaan air bersih yaitu meliputi persyaratan kualitatif, persyaratan kuantitatif dan persyaratan kontinuitas serta persyaratan tekanan air.

1. Persyaratan Kualitatif 
Persyaratan kualitatif adalah persyaratan yang menggambarkan mutu atau kualitas air bersih. Persyaratan kualitatif ini meliputi persyaratan fisik, persyaratan kimia, persyaratan biologis dan persyaratan radiologis.

a. Syarat fisik

Syarat fisik yang harus dimiliki oleh air bersih yaitu:

- Air tidak boleh berwarna (jernih);

- Air tidak boleh berasa;

- Air tidak boleh berbau;

- Suhu air hendaknya dibawah udara (sejuk $\left.\pm 25^{\circ} \mathrm{C}\right)$;

b. Syarat kimia

Air bersih yang layak tidak boleh mengandung bahan-bahan kimia dalam jumlah yang melampaui batas. Beberapa kandungan zat kimia yang selalu teradapat dalam air antara lain adalah $\mathrm{pH}$, total solid, zat organik, $\mathrm{CO}_{2}$ agresif, kesadahan, Kalsium (Ca), Besi (Fe), Mangan (Mn), Tembaga (Cu), Seng (Zn), Chlorida (Cl), Nitrit $\left(\mathrm{NO}_{2}\right)$, Flourida $(\mathrm{F})$, serta logam berat.

c. Syarat radiologis

Syarat radiologis dalam air bersih adalah persyaratan yang mengharuskan air bersih bebas dari kandungan bahan-bahan yang tercemar zat radioaktif seperti sinar alfa, beta dan gamma dan juga limbah pembuangan seperti akibat dari pembangkit listrik tenaga nuklir.

\section{Persyaratan Kuantitatif}

Persyaratan kuantitatif dalam penyediaan air bersih adalah persyaratan yang menjelaskan tentang kuantitas dari air baku yang kemudian akan diolah menjadi air bersih siap guna. Kuantitas air baku tersebut berpengaruh dalam pemenuhan kebutuhan air bersih penduduk di suatu daerah yang dilayani. Selain ditinjau dari banyaknya jumlah air baku yang akan diolah menjadi air bersih, persyaratan kuantitatif juga dapat ditinjau dari standar debit air bersih yang dialirkan ke konsumen yang menggunakan air bersih tersebut. Kebutuhan air bersih masyarakat umum bervariasi tergantung pada letak geografis, kebudayaan, tingkat ekonomi, dan lingkungan tempat tinggal.

3. Persyaratan Kontinuitas 
Persyaratan kontinuitas yang dimaksud adalah bahwa air baku yang merupakan sumber air bersih harus dapat diambil secara terus menerus dengan besar debit yang relatif tetap.

\section{Persyaratan Tekanan air}

Persyaratan tekanan air merupakan persyaratan yang menjelaskan tentang bagaimana air bersih yang akan dialirkan ke konsumen memiliki tekanan yang cuku dan stabil sehingga dapat melayani kebutuhan masyarakat setiap waktu dengan efektif dan efisien.

\section{Proyeksi Jumlah Penduduk}

Menurut Anonimus, (1990), dalam Standar Kriteria Desain Sistem Penyediaan Air Bersih, proyeksi jumlah penduduk di masa yang akan datang dapat diprediksikan berdasarkan laju pertumbuhan penduduk yang direncanakan.

1. Metode Aritmatika

Proyeksi penduduk dengan metode aritmatika mengasumsikan bahwa jumlah penduduk pada masa yang akan datang akan bertambah dengan jumlah yang sama setiap tahun. Hasil proyeksi akan berbentuk suatu garis lurus.

Formula yang digunakan pada metode proyeksi aritmatika adalah

$$
P_{n}=P_{0} \times(1+n \times r)
$$

dimana angka pertumbuhan penduduk $r=\frac{\left(\frac{P_{n}}{P_{0}}\right)-1}{t}$ dengan :

$$
\begin{array}{ll}
\text { Pn } & \text { adalah jumlah penduduk pada tahun } \mathrm{n} \\
\mathrm{P0} & \text { adalah jumlah penduduk pada tahun dasar } \\
\mathrm{r} & \text { adalah angka pertumbuhan penduduk } \\
\mathrm{t} & \text { adalah selisih antara tahun dasar dengan tahun } \mathrm{n}
\end{array}
$$

\section{Metode Geometrik}

Proyeksi penduduk dengan metode geometri menggunakan asumsi bahwa jumlah penduduk akan bertambah secara geometri dengan menggunakan dasar perhitungan majemuk (Adioetomo dan Samosir, 2010). Laju pertumbuhan penduduk (rate of growth) dianggap sama untuk setiap tahun. 
Formula yang digunakan pada metode geometri adalah:

$$
P_{n}=P_{0} \times(1+r)^{n}
$$

dimana angka pertumbuhan penduduk $r=\frac{\left(\frac{P_{n}}{P_{0}}\right)^{1 / t}}{t}-1$

3. Metode Eksponensial

Metode eksponensial menggambarkan pertambahan penduduk yang terjadi secara sedikit-sedikit sepanjang tahun, berbeda dengan metode geometri yang mengasumsikan bahwa pertambahan penduduk hanya terjadi pada satu saat selama kurun waktu tertentu (Adioetomo dan Samosir 2010).

Formula yang digunakan pada metode eksponensial adalah:

$$
P_{n}=P_{0} \times e^{(n \times r)}
$$

dimana angka pertumbuhan penduduk $r=\frac{\left\{\ln \left(\frac{P_{n}}{P_{0}}\right)\right\}}{t}$

Keterangan: $\quad$ Pn $\quad=$ Jumlah penduduk pada tahun $\mathrm{n}$ (jiwa)

Po = Jumlah penduduk pada tahun awal (jiwa)

$\mathrm{n} \quad=$ Periode waktu dalam tahun

$\mathrm{r} \quad=$ Laju pertumbuhan penduduk $(\%)$

\section{Kebutuhan Air Bersih}

Kebutuhan air bersih adalah banyaknya air yang diperlukan untuk melayani kebutuhan penduduk pada suatu wilayah atau daerah tertentu. Ada beberapa faktor yang mempengaruhi penggunaan air bersih dalam kebutuhannya bagi masyarakat, antara lain adalah iklim, karateristik penduduk, lokasi perindustrian, kualitas air dan harga air. Untuk memproyeksi jumlah kebutuhan air bersih dapat dilakukan berdasarkan perkiraan kebutuhan air untuk berbagai macam tujuan dan beberapa faktor kebutuhan.

\section{Kebutuhan Air Bersih Domestik}

Kebutuhan air domestik adalah kebutuhan yang bertujuan untuk memenuhi kebutuhan air bersih bagi keperluan rumah tangga yang dilakukan melalui Sambungan Rumah (SR) dan kebutuhan umum yang disediakan melalui fasilitas Hidran Umum (HU). Ada dua 
Jurnal Visi Eksakta (JVIEKS)

Vol.2, No.2, Juli 2021, pp.186-204

https://ejournal.uhn.ac.id/index.php/eksakta/

faktor yang perlu diperhatikan untuk memenuhi kebutuhan air bersih domestik masyarakat, yaitu:

a. Jumlah penduduk yang akan dilayani menurut target tahapan perencanaan sesuai dengan rencana cakupan pelayanan;

b. Tingkat pemakaian air bersih diasumsikan tergantung pada kategori daerah dan jumlah penduduknya.

Kebutuhan air bersih penduduk juga dibagi berdasarkan jenis kota dan jumlah penduduk di suatu wilayah tertentu seperti yang tertera pada Tabel 1 berikut.

Tabel 1 Kebutuhan Air Bersih Berdasarkan Jenis Kota dan Jumlah

\begin{tabular}{|c|c|c|c|}
\hline No. & Kategori & $\begin{array}{c}\text { Jumlah Penduduk } \\
\text { (jiwa) }\end{array}$ & $\begin{array}{c}\text { Pemakaian Air } \\
\text { (liter/hari/jiwa) }\end{array}$ \\
\hline 1. & Metropolitan & $>1.000 .000$ & 150 \\
\hline 2. & Kota Besar & $500.000-1.000 .000$ & 120 \\
\hline 3. & Kota Kecil & $100.000-500.000$ & 100 \\
\hline 4. & Kota Sedang & $25.000-100.000$ & 90 \\
\hline 5. & Ibukota Kecamatan & $10.000-25.000$ & 60 \\
\hline 6. & Pedesaan & $<10.000$ & 50 \\
\hline
\end{tabular}

Sumber: Cipta Karya, 1998.

Kota Medan merupakan kota metropolitan dan memiiki jumlah penduduk sebesar 2 juta jiwa, maka berdasarkan tabel diatas kebutuhan air bersih Kota Medan sebesar 150/liter/hari/jiwa.

\section{Kebutuhan Air Bersih Non-Domestik}

Kebutuhan air bersih non-domestik dialokasikan pada pelayanan untuk memenuhi kebutuhan air bersih berbagai fasilitas sosial (mesjid, panti asuhan, rumah sakit dan sebagainya), dan komersial yaitu fasilitas pendidikan, peribadatan, hotel, pusat pelayanan kesehatan, instansi pemerintahan dan perniagaan, fasilitas perdagangan, fasilitas industri, fasilitas perkantoran dan lain-lainnya. Besarnya pemakaian air untuk kebutuhan non-domestik diperhitungkan $20 \%$ dari kebutuhan domestik. 
Jurnal Visi Eksakta (JVIEKS)

Vol.2, No.2, Juli 2021, pp.186-204

https://ejournal.uhn.ac.id/index.php/eksakta/

\section{Kebutuhan Air Rata-Rata}

Kebutuhan air rata-rata perharinya adalah jumlah kebutuhan air untuk keperluan domestik ditambahkan dengan kebutuhan air untuk keperluan non-domestik dan ditambahkan dengan kehilangan air. Untuk data kehilangan air didapat dari $20 \%$ dari jumlah kebutuhan air domestik ditambah non-domestik.

\section{Fluktuasi Kebutuhan Air}

Kebutuhan air pada suatu daerah tidak selalu sama untuk setiap saat dan setiap harinya. Kebutuhan air tersebut akan mengalami fluktuasi sesuai dengan aktivitas penggunaan air selama proses pemakainnya dan juga tergantung pada keseharian masyarakat pengguna air. Kebutuhan air itu sendiri terbagi ke dalam tiga kelompok kebutuhan, yaitu:

$\checkmark$ Kebutuhan rata-rata (Qr);

$\checkmark$ Kebutuhan harian maksimum (Qm);

$\checkmark$ Kebutuhan pada jam puncak.

Mengetahui kebutuhan harian maksimum dan kebutuhan pada jam puncak pemakaian sangat diperlukan dalam memperhitungkan besarnya kebutuhan air baku. Kebutuhan air harian maksimum dan kebutuhan pada jam puncak pemakaian dapat dihitung dengan cara sebagai berikut:

a. Kebutuhan harian maksimum $=(1,2-1,5) \times$ kebutuhan air rata-rata;

b. Kebutuhan pada jam puncak $\quad=(1,5-2) \times$ kebutuhan harian maksimum.

\section{METODOLOGI PENELITIAN}

\section{Lokasi Penelitian}

Penelitian ini berolakasi di Kota Medan dimana wilayah yang ditinjau adalah 21 kecamatan di kota tersebut.

\section{Geografis}

Kota Medan memiliki luas 26.510 hektare $\left(265,10 \mathrm{~km}^{2}\right)$ atau 3,6\% dari keseluruhan wilayah Sumatra Utara. Dengan demikian, dibandingkan dengan kota/kabupaten lainya, Medan memiliki luas wilayah yang relatif kecil dengan jumlah penduduk yang relatif besar. Secara geografis kota Medan terletak pada $3^{\circ} 30^{\prime}-3^{\circ} 43^{\prime}$ Lintang Utara dan $98^{\circ} 35^{\prime}-98^{\circ} 44^{\prime}$ Bujur Timur. 
Jurnal Visi Eksakta (JVIEKS)

Vol.2, No.2, Juli 2021, pp.186-204

https://ejournal.uhn.ac.id/index.php/eksakta/

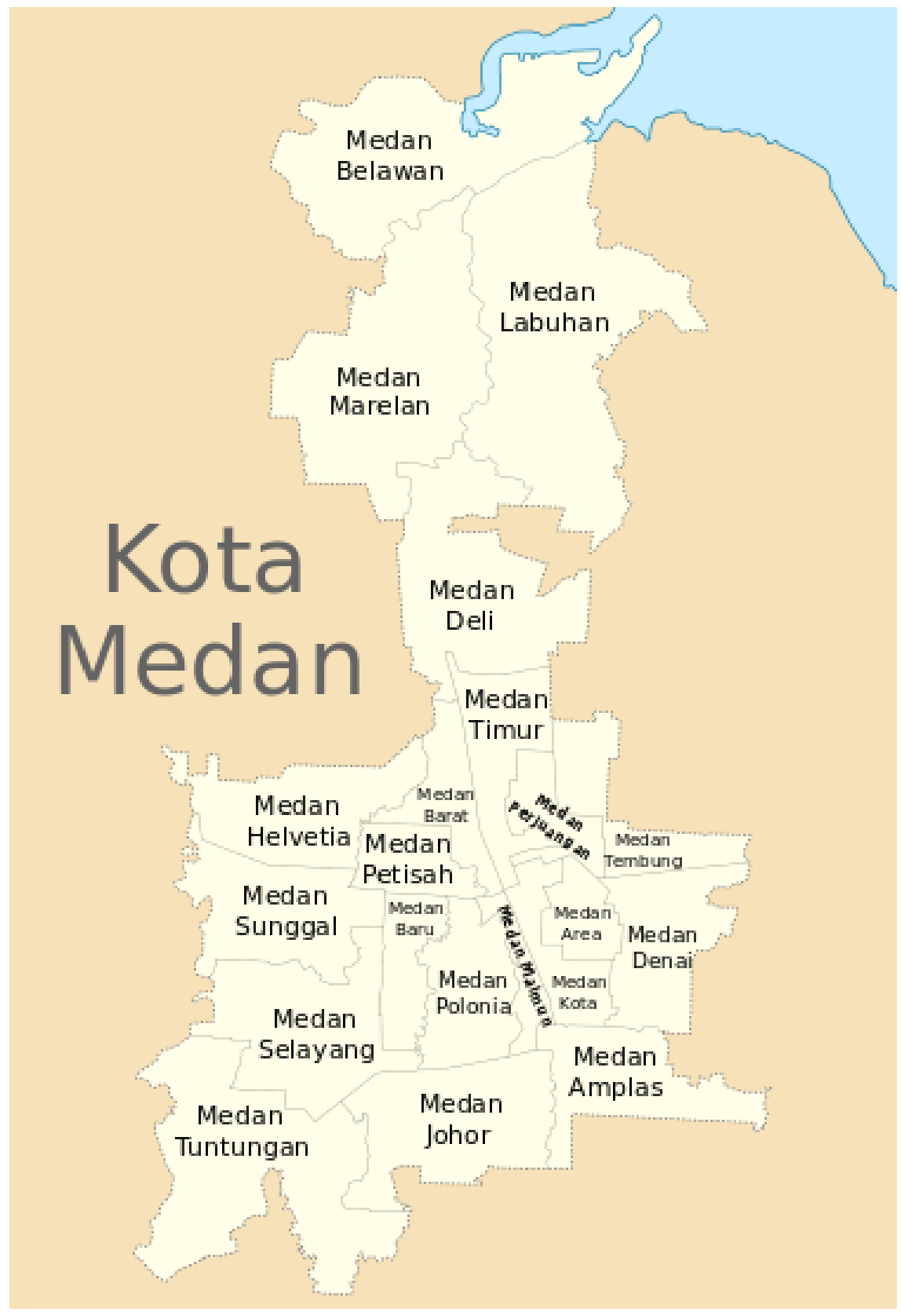

Gambar 1. Peta Administrasi Kota Medan

\section{Tahapan Penelitian}

1. Studi Pustaka

Tahap studi pustaka yaitu mengumpulkan dan mempelajari bahan-bahan yang berhubungan dengan masalah-masalah yang diteliti. Bahan-bahan tersebut berupa bahan 
yang didapat dari tulisan-tulisan ilmiah, diktat-diktat, buku-buku maupun internet yang berkaitan dengan masalah yang diteliti. Dalam hal ni data yang diperoleh berupa literatur yang berkaitan dengan masalah yang akan dibahas.

2. Pengumpulan Data

Tahap ini merupakan tahap pengumpulan data-data yang berhubungan dengan analisa kebutuhan air. Beberapa data yang dikumpulkan, yaitu:

a. Data jumlah penduduk tahun 2014 samapai tahun 2018 untuk 21 kecamatan di Kota Medan;

b. Data kapasitas produksi air PDAM.

\section{Pengolahan Data}

Dalam tahap ini yang dilakukan adalah mengolah data yang sudah didapat untuk dijadikan data awal dalam melakukan analisa dan perhitungan. Perhitungan yang dilakukan berkaitan dengan analisa kebutuhan air bersih yaitu kebutuhan air domestik dan non-domestik pada kondisi sekarang dan yang akan datang di Kota Medan.

4. Analisis dan Pembahasan

Sebelum dilakukan perhitungan, terlebih dahulu dilakukan pemeriksaan data-data yang sudah dikumpulkan apakah sudah sesuai dengan data yang sebenarnya atau tidak. Setelah semua data diperiksa, maka dilakukan perhitungan. Adapun tahapan perhitungan yang dilakukan, yaitu :

a. Perhitungan proyeksi penduduk di Kota Medan;

b. Analisa Kebutuhan air bersih yaitu kebutuhan air domestik dan non-domestik. 
Jurnal Visi Eksakta (JVIEKS)

Vol.2, No.2, Juli 2021, pp.186-204

https://ejournal.uhn.ac.id/index.php/eksakta/

\section{Diagram Alur Penelitian}

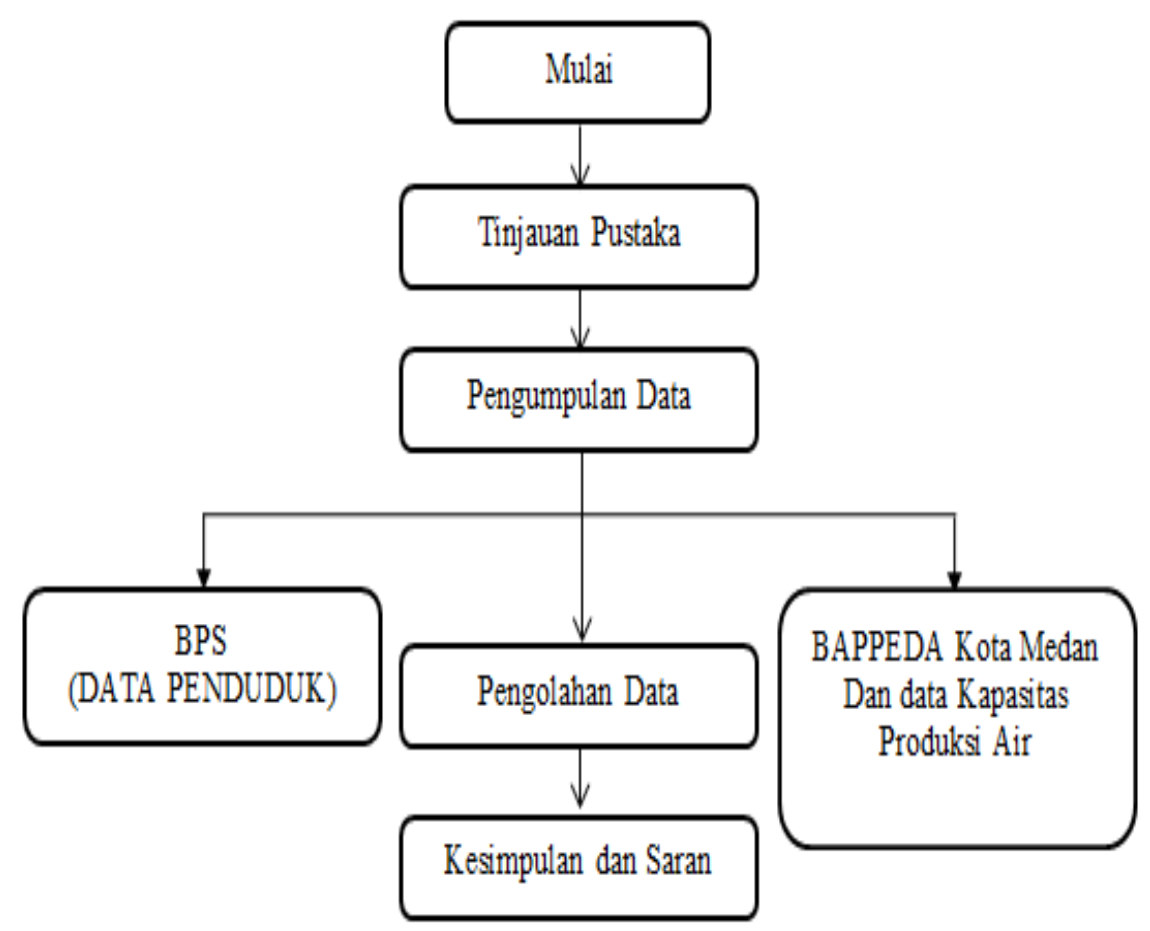

Gambar 2. Diagram Alir Pelaksanaan Penelitian

HASIL DAN PEMBAHASAN

Data Penduduk Kota Medan Tahun 2014 - 2018

Tabel 2. Data Penduduk Kota Medan Tahun 2014 Sampai Tahun 2018

\begin{tabular}{|c|l|c|c|c|c|c|}
\hline \multirow{2}{*}{ No } & \multirow{2}{*}{ Kecamatan } & \multicolumn{5}{|c|}{ Jumlah Penduduk } \\
\cline { 3 - 7 } & & 2014 & 2015 & 2016 & 2017 & 2018 \\
\hline \hline 1 & Medan Amplas & 121.362 & 123.850 & 126.340 & 127.361 & 129.323 \\
\hline 2 & Medan Area & 98.955 & 98.992 & 99.021 & 99.821 & 99.993 \\
\hline 3 & Medan Barat & 72.620 & 72.683 & 72.717 & 73.305 & 73.424 \\
\hline 4 & Medan Baru & 40.519 & 40.540 & 40.560 & 40.888 & 40.963 \\
\hline 5 & Medan Belawan & 98.020 & 98.113 & 98.167 & 98.960 & 99.273 \\
\hline 6 & Medan Deli & 178.147 & 181.460 & 184.762 & 186.255 & 188.807 \\
\hline 7 & Medan Denai & 145.677 & 146.061 & 146.388 & 147.571 & 147.981 \\
\hline
\end{tabular}


Jurnal Visi Eksakta (JVIEKS)

Vol.2, No.2, Juli 2021, pp.186-204

https://ejournal.uhn.ac.id/index.php/eksakta/

\begin{tabular}{|c|l|c|c|c|c|c|}
\hline 8 & Medan Helvetia & 149.806 & 150.721 & 151.581 & 152.806 & 153.989 \\
\hline 9 & Medan Johor & 130.414 & 132.012 & 133.577 & 134.656 & 136.069 \\
\hline 10 & Medan Kota & 74.406 & 74.439 & 74.461 & 75.063 & 75.153 \\
\hline 11 & Medan Labuhan & 116.357 & 117.472 & 118.551 & 119.509 & 120.861 \\
\hline 12 & Medan Maimun & 40.624 & 40.663 & 40.690 & 41.020 & 41.092 \\
\hline 13 & Medan Marelan & 156.394 & 162.267 & 167.984 & 169.342 & 172.456 \\
\hline 14 & Medan Perjuangan & 95.790 & 95.882 & 95.936 & 96.711 & 96.848 \\
\hline 15 & Medan Petisah & 63.333 & 63.374 & 63.390 & 63.902 & 63.992 \\
\hline 16 & Medan Polonia & 55.369 & 55.949 & 56.513 & 56.970 & 57.501 \\
\hline 17 & Medan Selayang & 104.454 & 106.150 & 107.831 & 108.702 & 109.926 \\
\hline 18 & Medan Sunggal & 115.687 & 115.785 & 115.837 & 116.773 & 117.189 \\
\hline 19 & Medan Tembung & 137.062 & 137.178 & 137.239 & 138.348 & 138.884 \\
\hline 20 & Medan Timur & 111.369 & 111.420 & 111.438 & 112.339 & 112.482 \\
\hline 21 & Medan Tuntungan & 84.775 & 85.613 & 86.425 & 87.123 & 87.939 \\
\hline \multicolumn{2}{r|}{ Total } & $\mathbf{2 . 1 9 1 . 1 4 0}$ & $\mathbf{2 . 2 1 0 . 6 2 4}$ & $\mathbf{2 . 2 2 9 . 4 0 8}$ & $\mathbf{2 . 2 4 7 . 4 2 5}$ & $\mathbf{2 . 2 6 4 . 1 4 5}$ \\
\hline
\end{tabular}

Sumber : BPS Provinsi Sumatera Utara

Proyeksi Pertumbuhan Penduduk

Tabel 3. Proyeksi Penduduk Kota Medan Tahun 2025

\begin{tabular}{|c|l|c|c|c|}
\hline No. & Kecamatan & $\begin{array}{c}\text { Metode Geometrik } \\
\text { (jiwa) }\end{array}$ & $\begin{array}{c}\text { Metode Aritmatik } \\
\text { (jiwa) }\end{array}$ & $\begin{array}{c}\text { Rata- rata } \\
\text { (jiwa) }\end{array}$ \\
\hline \hline 1 & Medan Amplas & 144.544 & 137.284 & 140.914 \\
\hline 2 & Medan Area & 101.839 & 101.031 & 101.435 \\
\hline 3 & Medan Barat & 74.855 & 74.228 & 74.541 \\
\hline 4 & Medan Baru & 41.753 & 41.407 & 41.580 \\
\hline 5 & Medan Belawan & 101.508 & 100.526 & 101.017 \\
\hline 6 & Medan Deli & 209.033 & 199.467 & 204.250 \\
\hline 7 & Medan Denai & 152.104 & 150.285 & 151.195 \\
\hline 8 & Medan Helvetia & 161.593 & 158.172 & 159.882 \\
\hline 9 & Medan Johor & 146.563 & 141.724 & 144.144 \\
\hline 10 & Medan Kota & 76.481 & 75.900 & 76.191 \\
\hline 11 & Medan Labuhan & 129.167 & 125.365 & 127.266 \\
\hline 12 & Medan Maimun & 41.925 & 41.560 & 41.743 \\
\hline 13 & Medan Marelan & 204.736 & 188.518 & 196.627 \\
\hline
\end{tabular}

Received May $2^{\text {rd }}$, 2021; Revised June 5 ${ }^{\text {th }}$, 2021; Accepted July, 2021 
Jurnal Visi Eksakta (JVIEKS)

Vol.2, No.2, Juli 2021, pp.186-204

https://ejournal.uhn.ac.id/index.php/eksakta/

\begin{tabular}{|c|l|c|c|c|}
\hline 14 & Medan Perjuangan & 98.731 & 97.906 & 98.318 \\
\hline 15 & Medan Petisah & 65.164 & 64.651 & 64.908 \\
\hline 16 & Medan Polonia & 61.432 & 59.633 & 60.532 \\
\hline 17 & Medan Selayang & 120.205 & 115.398 & 117.802 \\
\hline 18 & Medan Sunggal & 119.868 & 118.691 & 119.280 \\
\hline 19 & Medan Tembung & 142.136 & 140.706 & 141.421 \\
\hline 20 & Medan Timur & 114.461 & 113.595 & 114.028 \\
\hline 21 & Medan Tuntungan & 93.763 & 91.103 & 92.433 \\
\hline
\end{tabular}

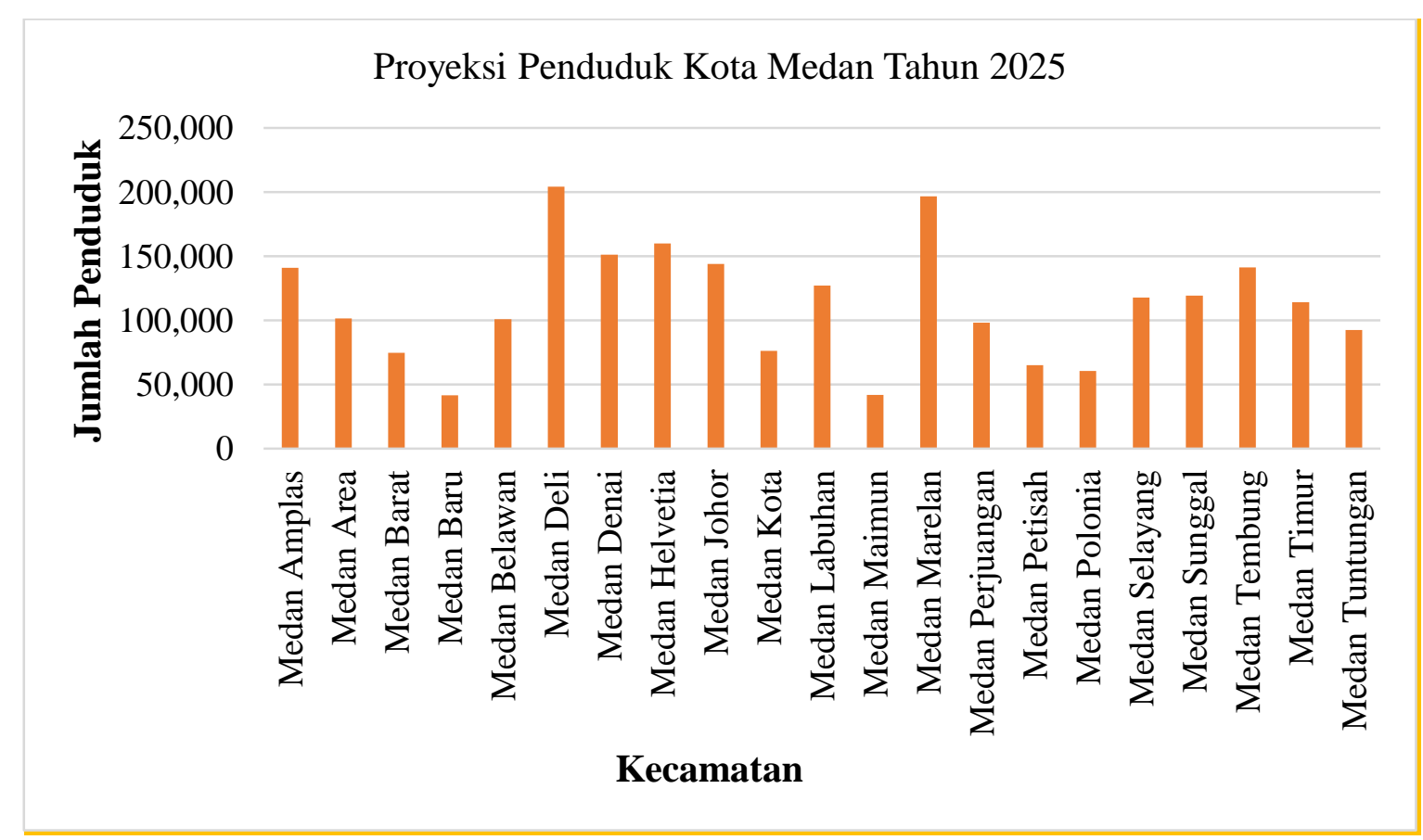

Gambar 3. Grafik Proyeksi Penduduk Kota Medan Tahun 2025

Berikut adalah tabel hasil perhitungan proyeksi penduduk Kota Medan tahun 2018 sampai dengan tahun 2025.

Tabel 4. Proyeksi Penduduk Kota Medan Tahun 2018 - 2025

\begin{tabular}{|c|c|c|}
\hline No & Tahun & $\begin{array}{c}\text { Jumlah } \\
\text { Penduduk (jiwa) }\end{array}$ \\
\hline \hline 1 & 2018 & 2.264 .145 \\
\hline 2 & 2019 & 2.278 .803 \\
\hline 3 & 2020 & 2.293 .588 \\
\hline 4 & 2021 & 2.308 .503 \\
\hline 5 & 2022 & 2.323 .550 \\
\hline
\end{tabular}

Received May $2^{\text {rd }}$, 2021; Revised June 5 ${ }^{\text {th }}$ 2021; Accepted July, 2021 
Jurnal Visi Eksakta (JVIEKS)

Vol.2, No.2, Juli 2021, pp.186-204

https://ejournal.uhn.ac.id/index.php/eksakta/

\begin{tabular}{|l|l|l|}
\hline 6 & 2023 & 2.338 .731 \\
\hline 7 & 2024 & 2.354 .049 \\
\hline 8 & 2025 & 2.369 .506 \\
\hline
\end{tabular}

\section{Proyeksi Kebutuhan Air}

\section{Kebutuhan Air Domestik \& Non-Domestik}

Dalam perencanaan perhitungan kebutuhan air, perlu di analisis kebutuhan air domestik dan non domestik, karena sama-sama membutuhkan infrastruktur air bersih. Pada Tabel 5 berikut, dapat dilihat Proyeksi Kebutuhan Air Domestik \& Non-Domestik Kota Medan Tahun 2025.

Tabel 5. Proyeksi Kebutuhan Air Domestik \& Non-Domestik Kota Medan Tahun 2025

\begin{tabular}{|c|l|c|c|c|c|}
\hline No & Kecamatan & $\begin{array}{c}\text { Jumlah } \\
\text { Jiwa }\end{array}$ & $\begin{array}{c}\text { Konsumsi Air } \\
\text { Rata - Rata } \\
\text { Lt/Jiwa/Hari) }\end{array}$ & $\begin{array}{c}\text { Kebutuhan } \\
\text { Air Domestik } \\
\text { (Lt/Detik) }\end{array}$ & $\begin{array}{c}\text { Kebutuhan Air } \\
\text { Non-Domestik } \\
\text { (Lt/Detik) }\end{array}$ \\
\hline \hline 1 & Medan Amplas & 140.914 & 150 & 244,64 & 48,93 \\
\hline 2 & Medan Area & 101.435 & 150 & 176,10 & 35,22 \\
\hline 3 & Medan Barat & 74.541 & 150 & 129,41 & 25,88 \\
\hline 4 & Medan Baru & 41.580 & 150 & 72,19 & 14,44 \\
\hline 5 & Medan Belawan & 101.017 & 150 & 175,38 & 35,08 \\
\hline 6 & Medan Deli & 204.250 & 150 & 354,60 & 70,92 \\
\hline 7 & Medan Denai & 151.195 & 150 & 262,49 & 52,50 \\
\hline 8 & Medan Helvetia & 159.882 & 150 & 277,57 & 55,52 \\
\hline 9 & Medan Johor & 144.144 & 150 & 250,25 & 50,05 \\
\hline 10 & Medan Kota & 76.191 & 150 & 132,28 & 26,46 \\
\hline 11 & Medan Labuhan & 127.266 & 150 & 220,95 & 44,19 \\
\hline 12 & Medan Maimun & 41.743 & 150 & 72,47 & 14,49 \\
\hline 13 & Medan Marelan & 196.627 & 150 & 341,37 & 68,27 \\
\hline 14 & Medan Perjuangan & 98.318 & 150 & 170,69 & 34,14 \\
\hline 15 & Medan Petisah & 64.908 & 150 & 112,69 & 22,54 \\
\hline 16 & Medan Polonia & 60.532 & 150 & 105,09 & 21,02 \\
\hline 17 & Medan Selayang & 117.802 & 150 & 204,52 & 40,90 \\
\hline 18 & Medan Sunggal & 119.280 & 150 & 207,08 & 41,42 \\
\hline 19 & Medan Tembung & 141.421 & 150 & 245,52 & 49,10 \\
\hline 20 & Medan Timur & 114.028 & 150 & 197,97 & 39,59 \\
\hline 21 & Medan Tuntungan & 92.433 & 150 & 160,47 & 32,10 \\
\hline & Total & $\mathbf{2 . 3 6 9 . 5 0 7}$ & & $\mathbf{4 . 1 1 3 , 7 3}$ & $\mathbf{8 2 2 , 7 5}$ \\
\hline
\end{tabular}


Jurnal Visi Eksakta (JVIEKS)

Vol.2, No.2, Juli 2021, pp.186-204

https://ejournal.uhn.ac.id/index.php/eksakta/

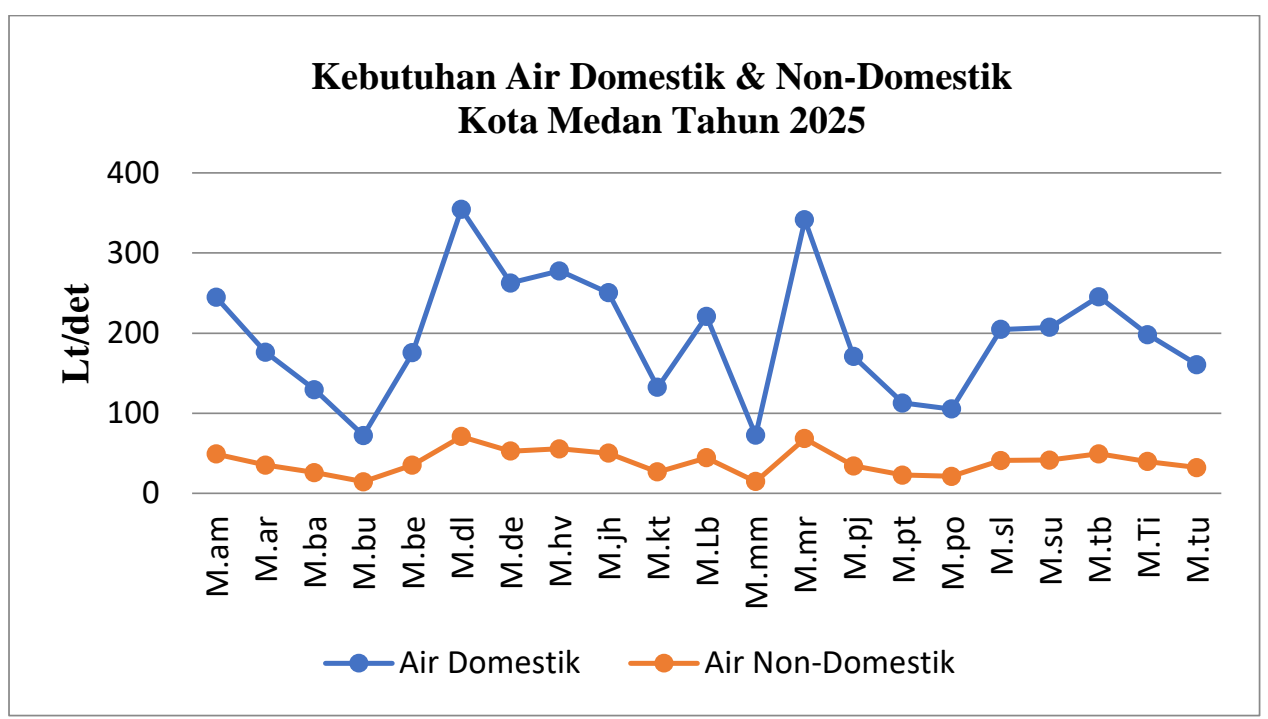

Gambar 4. Grafik Proyeksi Kebutuhan Air Domestik \& Non-Domestik Kota Medan Tahun 2025

\section{Kebutuhan Air Rata-Rata}

Tabel 6. Total Kebutuhan Air Rata-Rata di Kota Medan Tahun 2018 - 2025

\begin{tabular}{|c|c|c|c|c|c|}
\hline Tahun & $\begin{array}{c}\text { Kebutuhan } \\
\text { Air } \\
\text { Domestik } \\
\text { (Lt/Detik) }\end{array}$ & $\begin{array}{c}\text { Kebutuhan } \\
\text { air non- } \\
\text { domestik } \\
\text { (Lt/Detik) }\end{array}$ & $\begin{array}{c}\text { Kebutuhan Air } \\
\text { domestik \& } \\
\text { non domestik } \\
\text { (Lt/Detik) }\end{array}$ & $\begin{array}{c}\text { Kehilangan } \\
\text { Air } \\
\text { (Lt/Detik) }\end{array}$ & $\begin{array}{c}\text { Kebutuhan } \\
\text { Air rata- } \\
\text { rata } \\
\text { (Lt/Detik) }\end{array}$ \\
\hline 2018 & $3.930,81$ & 786,16 & $4.716,97$ & 943,39 & $5.660,36$ \\
\hline 2019 & $3.956,26$ & 791,25 & $4.747,51$ & 949,50 & $5.697,01$ \\
\hline 2020 & $3.981,92$ & 796,39 & $4.778,31$ & 955,66 & $5.733,97$ \\
\hline 2021 & $4.007,82$ & 801,56 & $4.809,38$ & 961,88 & $5.771,26$ \\
\hline 2022 & $4.033,94$ & 806,79 & $4.840,73$ & 968,15 & $5.808,88$ \\
\hline 2023 & $4.060,30$ & 812,06 & $4.872,36$ & 974,47 & $5.846,83$ \\
\hline 2024 & $4.086,89$ & 817,38 & $4.904,27$ & 980,85 & $5.885,12$ \\
\hline 2025 & $4.113,73$ & 822,75 & $4.936,47$ & 987,29 & $5.923,77$ \\
\hline
\end{tabular}


Jurnal Visi Eksakta (JVIEKS)

Vol.2, No.2, Juli 2021, pp.186-204

https://ejournal.uhn.ac.id/index.php/eksakta/

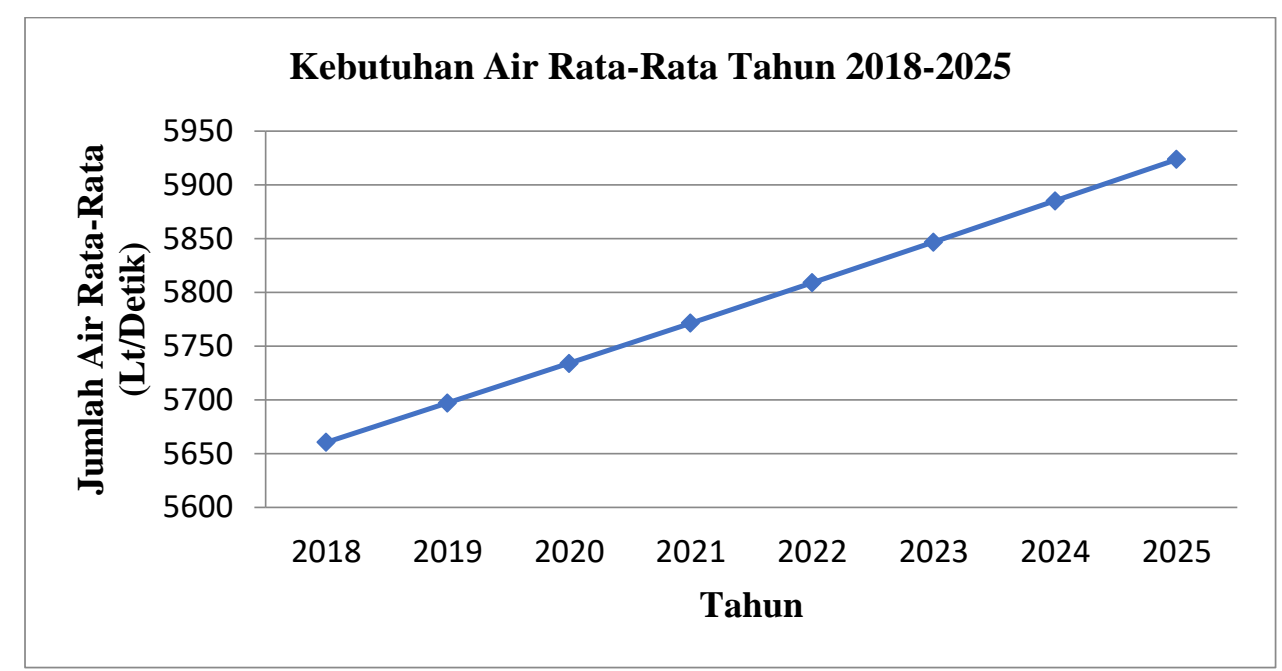

Gambar 5. Kebutuhan Air Rata-Rata Kota Medan Tahun 2018-2025

\section{Kebutuhan Air Harian Maksimum dan Jam Puncak}

Tabel 7. Kebutuhan Air Harian Maksimum dan Jam Puncak di Kota Medan

\begin{tabular}{|c|c|c|}
\hline Tahun & $\begin{array}{c}\text { Kebutuhan Air } \\
\text { Maksimum } \\
\text { (Lt/Detik) }\end{array}$ & $\begin{array}{c}\text { Kebutuhan Pada } \\
\text { Jam Puncak } \\
\text { (Lt/detik) }\end{array}$ \\
\hline \hline 2018 & $6.792,44$ & $10.188,65$ \\
\hline 2019 & $6.836,41$ & $10.254,61$ \\
\hline 2020 & $6.880,77$ & $10.321,15$ \\
\hline 2021 & $6.925,51$ & $10.388,27$ \\
\hline 2022 & $6.970,65$ & $10.455,98$ \\
\hline 2023 & $7.016,19$ & $10.524,29$ \\
\hline 2024 & $7.062,15$ & $10.593,22$ \\
\hline 2025 & $7.108,52$ & $10.662,78$ \\
\hline
\end{tabular}

Bila dibandingkan dengan proyeksi kebutuhan air di kota medan didalam dokumen RISPAM kota medan tahun 2015 pada Tabel 48 halaman 81, untuk tahun 2024 proyeksi kebutuhan airnya yaitu 10.114,18 Lt/det. Dan dari hasil penelitian ini menunjukkan juga bahwa sangatlah mendekati besaran proyeksi kebutuhan air kota medan untuk tahun 2025 yaitu $10.662,78 \mathrm{Lt} / \mathrm{det}$. 
Jurnal Visi Eksakta (JVIEKS)

Vol.2, No.2, Juli 2021, pp.186-204

https://ejournal.uhn.ac.id/index.php/eksakta/

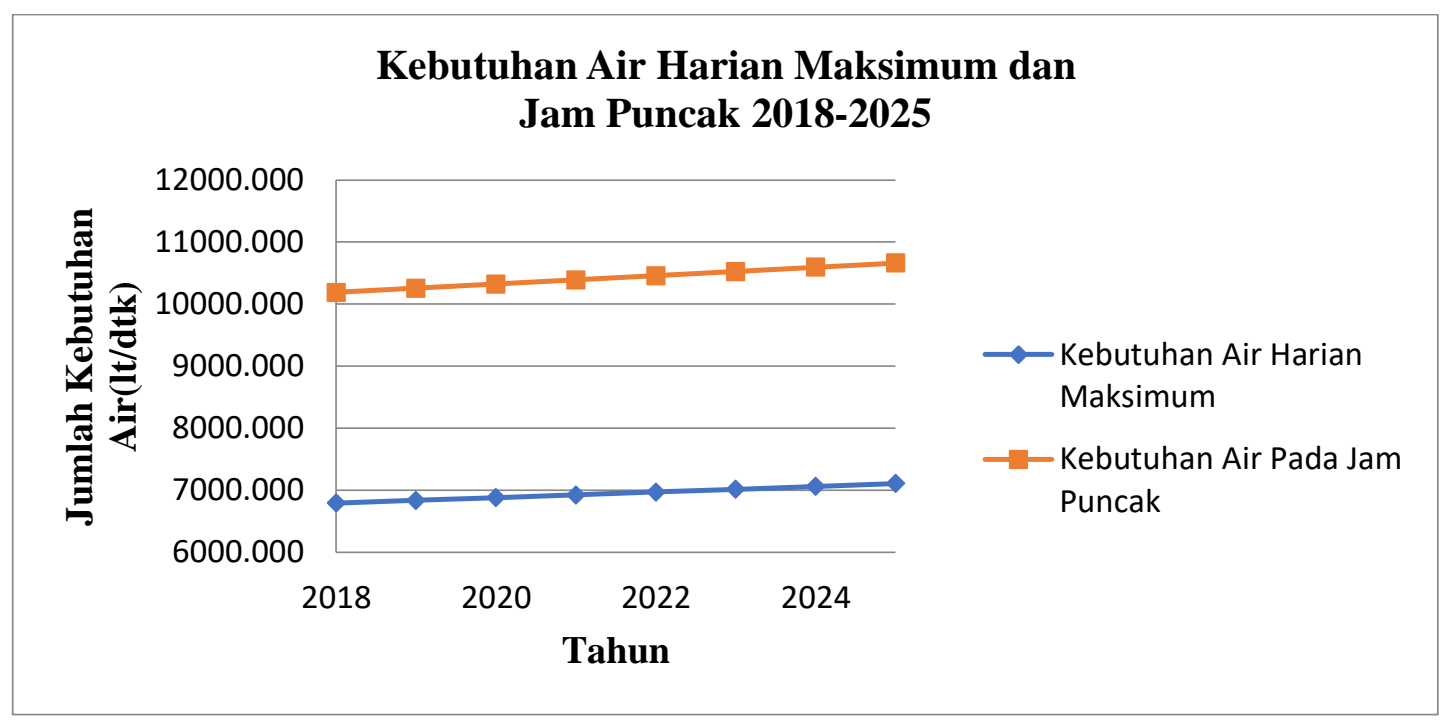

\section{Gambar 6. Kebutuhan Air Harian Maksimum dan Jam Puncak Kota Medan Tahun 2018-2025}

\section{KESIMPULAN DAN SARAN}

\section{Kesimpulan}

1. Dari tahun 2018 (awal perencanaan) sampai dengan tahun 2025 (akhir perencanaan) jumlah kebutuhan air bersih selalu mengalami kenaikan tiap tahun seiring dengan bertambahnya juga jumlah penduduk tiap tahun.

2. Pada awal perencanaan (2018)

- Jumlah penduduk sebanyak 2.264.145 jiwa

- Kebutuhan air rata-rata sebanyak 5660,363 liter/detik

- Kebutuhan air harian maksimum sebesar 6792,435 liter/detik

- Kebutuhan air pada jam puncak sebesar 10188,653 liter/detik

3. Pada akhir perencanaan (2025)

- Jumlah rumah tangga sebanyak 2.369.506 jiwa

- Kebutuhan air rata-rata sebanyak 5.923,77 liter/dtk

- Kebutuhan air harian maksimum sebesar 7.108,52 liter/detik

- Kebutuhan air pada jam puncak sebesar 10.662,78 liter/detik

4. Kapasitas produksi PDAM saat ini 5.347 liter/detik, sehingga kebutuhan air bersih untuk Kota Medan belum dapat terpenuhi. 
Jurnal Visi Eksakta (JVIEKS)

Vol.2, No.2, Juli 2021, pp.186-204

https://ejournal.uhn.ac.id/index.php/eksakta/

\section{Saran}

1. PDAM harus secara rutin melakukan penyuluhan tentang pentingnya menggunakan air bersih secara cermat dan hemat untuk menghindari krisis air bersih yang mungkin dapat sewaktu-waktu terjadi di Kota Medan.

2. Peningkatan kualitas pelayanan PDAM harus terus selalu ditingkatkan guna malayani kebutuhan masyarakat dan juga untuk mendapatkan kepercayaan masyarakat akan pelayanan air bersih yang dilakukan oleh perusahaan nasional dalam negeri.

\section{DAFTAR PUSTAKA}

Asmadi, dkk. 2011. Teknologi Pengolahan Air Minum. Yogyakarta: Gosyen Publishing Ir.Sutrisno, T., dkk, 2010. Teknologi Penyediaan Air Bersih. Jakarta: Rineka Cipta Kota Medan Dalam Angka 2015. Medan: Badan Pusat Statistik Sumatera Utara Kota Medan Dalam Angka 2016. Medan: Badan Pusat Statistik Sumatera Utara Kota Medan Dalam Angka 2017. Medan: Badan Pusat Statistik Sumatera Utara Kota Medan Dalam Angka 2018. Medan: Badan Pusat Statistik Sumatera Utara Kota Medan Dalam Angka 2019. Medan: Badan Pusat Statistik Sumatera Utara BAPPEDA Kota Medan

PDAM Tirtanadi Kota Medan 